\title{
PERAWATAN SALURAN AKAR NON BEDAH PADA GIGI ANTERIOR DENGAN LESI PERIAPIKAL YANG MELUAS (Laporan Kasus)
}

\author{
Mirza Aryanto \\ Staf pengajar Laboratorium Konservasi, FKG UPDMB, Jakarta
}

\begin{abstract}
ABSTRAK
Pendahuluan: kasus ini memperlihatkan lesi periapikal yang meluas pada gigi anterior. Perawatan saluran akar dilakukan secara konservatif, dengan mengaplikasikan medikasi intrakanal berupa kalsium hidroksida. Tujuan: setahun setelah perawatan memperlihatkan penyembuhan melalui berkurangnya ukuran lesi. Penatalaksanaan: perawatan saluran akar dilakukan dengan beberapa kali kunjungan menggunakan medikamen berupa kalsium hidroksida Kesimpulan: laporan kasus ini memperlihatkan keberhasilan perawatan saluran akar konvensional non bedah.
\end{abstract}

Kata kunci : perawatan saluran akar, lesi luas, kalsium hidroksida

\section{ABSTRACT}

Introduction: a large periapical lesion in relation to the central incisors is presented here. The root canal treatment was done conservatively, by placement of calcium hydroxide. Objective: periapical healing was observed at the one year recall. Case operative procedure: a root canal was done by using calcium hydroxide as medicament. Conclusion: this report confirms that for treatment of a large periapical lesion it is not always necessary to do surgical treatment and periapical lesions would heal following conservative endodontic therapy.

Key words: root canal treatment, large lesion, calcium hydroxide

\section{PENDAHULUAN}

$\mathrm{P}$ erawatan saluran akar konvensional telah lama menunjukkan tingkat keberhasilan yang tinggi. Namun perawatan saluran akar konvensional pada gigi nonvital dengan lesi periapikal yang meluas memiliki tingkat kegagalan yang tinggi. Biasanya pada lesi periapikal dengan diameter lebih dari $7 \mathrm{~mm}$ dilakukan pembedahan. Lesi periapikal dalam sebagian besar kasus dapat digolongkan sebagai granuloma periapikal, abses periapikal dan kista periapikal yang tidak dapat dibedakan satu sama lain berdasarkan pada radiograf saja. Lesi ini bisa berawal dari trauma gigi ataupun karies. Kemungkinan pulpa dapat bertahan tergantung pada tingkat keparahan trauma dan tipe reaksi inflamasi yang menyertai. Karena trauma, vaskularisasi pulpa mungkin berdegenerasi menjadi nekrosis vaskular dan menciptakan kondisi anaerobik untuk pertumbuhan mikroorganisme oportunistik. Material nekrotik keluar dari sistem saluran akar dan masuk ke dalam bagian pendukung perlekatan vaskular, menyebabkan lesi di daerah endodontik. ${ }^{1,2}$

Kebanyakan lesi periapeks (lebih dari 90\%) diklasifikasikan menjadi granuloma, kista radikuler atau abses. Terdapat bukti klinis bahwa semakin luas ukuran lesi, maka kemungkinannya adalah akibat kista radikuler. Namun, beberapa lesi luas dapat berupa granuloma atau abses. Diagnosis definitif hanya dapat dipastikan melalui analisis histologis. ${ }^{2,3}$

Kalsium hidroksida $\left[\mathrm{Ca}(\mathrm{OH})_{2}\right]$ telah digunakan selama lebih dari 1 abad sebagai medikamen intrakanal dalam endodontik. Penggunaan $\mathrm{Ca}(\mathrm{OH})_{2}$ sebagai obat saluran akar berhubungan dengan penyembuhan periradikuler, karena memiliki efek antibakterial dan dapat mendorong perbaikan tulang. ${ }^{4}$

Pada makalah ini, akan dibahas laporan kasus mengenai keberhasilan perawatan pada gigi anterior dengan lesi rPada makalah ini, akan dibahas laporan kasus mengenai keberhasilan perawatan pada gigi anterior dengan lesi radiolusensi yang luas dengan menggunakan pasta kalsium hidroksida sebagai medikasi intrakanal.

\section{KASUS}

Seorang pasien perempuan berusia 27 tahun datang dengan keluhan gigi depan atas kiri dan kanan patah akibat trauma jatuh dari motor. Pemeriksaan intraoral menunjukkan tanpa keluhan serta tidak ada bengkak pada gigi tersebut (Gambar 1). Saat dilakukan 
pemeriksaan foto periapikal, terlihat gambaran radiolusensi yang meluas pada bagian apikal gigi 11 dan 21 dengan batas jelas dan tegas (Gambar 2)

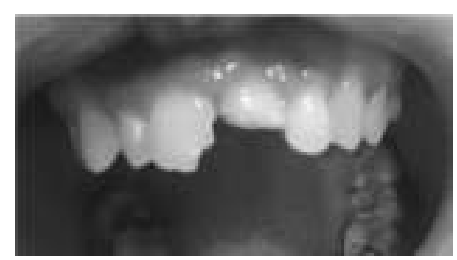

GAMBAR 1.

Gigi 11 dan 21 mengalami fraktur pada insisal akibat trauma.

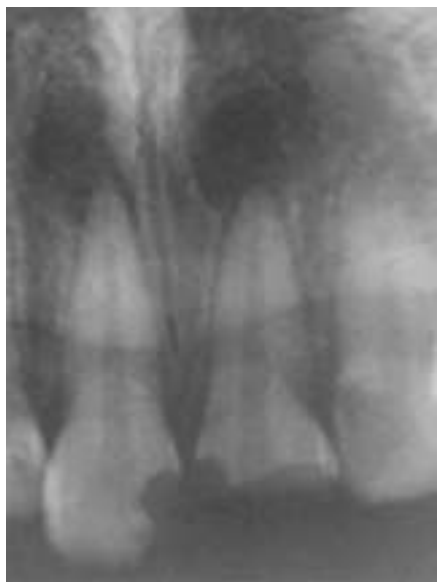

GAMBAR 2

Gambaran radiografik menunjukkan lesi radiolusen yang meluas pada gigi 11 dan 21

Hasil pemeriksaan dan riwayat pasien menunjukkan diagnosis sementara berupa kista periapikal pada gigi 11 dan 21. Perawatan saluran akar konvensional dilakukan pada kedua gigi tersebut.

\section{PENATALAKSANAAN}

Saat kunjungan pertama, dipasangkan isolator karet (rubber dam), kemudian dilakukan preparasi akses. Negoisasi saluran akar dilakukan dengan menggunakan file \#10 dan \#15, kemudian ditentukan file awal pada gigi 11 setara dengan file no 35 dan pada gigi 21 setara dengan file 30. Panjang kerja ditentukan menggunakan alat penentu apeks (Propex Mini, Dentsply), kemudian dilakukan preparasi saluran akar menggunakan mesin rotari menggunakan file Protaper, hingga mencapai F4 pada gigi 11 dan F5 pada gigi 21 (Gambar 3). Selama preparasi saluran akar, dinding saluran akar dilumasi menggunakan pasta EDTA 17\%. Kemudian diirigasi menggunakan cairan $\mathrm{NaOCl} 5,25 \%$ serta dilakukan aktivasi mengggunakan Endoactivator selama 60 detik pada tiap gigi (Gambar 4). Irigasi terakhir dilakukan menggunakan cairan Chlorhexidine (CHX) 2\%, kemudian dimasukkan pasta kalsium hidroksida, lalu diaplikasikan tambalan sementara.

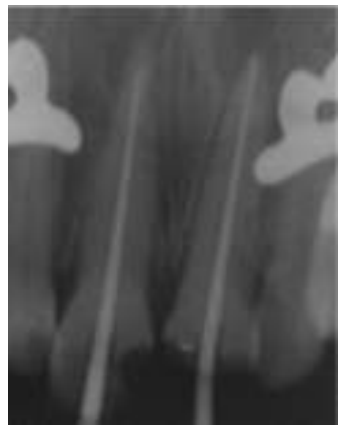

GAMBAR3.

Radiograf perhitungan panjang kerja $\mathrm{m}$ e $\mathrm{n} g \mathrm{~g}$ u $\mathrm{n}$ a $\mathrm{k}$ a $\mathrm{n}$ gutapercha.

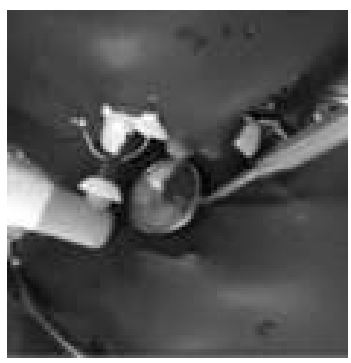

GAMBAR 4.

Endoactivator digunakan selama 60 detik.

Dua minggu kemudian, pasien datang kembali. Saluran akar diirigasi kembali serta dilakukan aplikasi pasta kalsium hidroksida. Pada awalnya, direncanakan dilakukan pemanggilan kembali 2 minggu setelahnya, namun pasien baru bisa datang kembali setelah satu bulan.

Saat kunjungan berikutnya, saluran akar dilakukan pembersihan dan pembentukan saluran akar, kemudian diirigasi menggunakan $\mathrm{NaOCl} 52,5 \%$, dikeringkan, kemudian pasta $\mathrm{Ca}(\mathrm{OH}) 2$ diaplikasikan kembali.

Tiga bulan kemudian, dilakukan pembukaan tambalan sementara dan diputuskan dilakukan obturasi setelah melihat keadaan klinisnya. Obturasi saluran akar dilakukan menggunakan gutta-percha protaper serta menggunakan sealer AH26. Pasien datang kembali seminggu setelah obturasi, kemudian dilakukan pemasangan pasak fiber serta dilakukan preparasi gigi untuk dibuatkan mahkota PFM (metal-porselen). Mahkota metal-porselen dipasangkan 1 minggu 
kemudian (Gambar 5).

Satu tahun setelah perawatan, dilakukan foto radiografik dan terlihat ukuran lesi yang semakin berkurang, serta hilangnya keluhan klinis (Gambar 6).

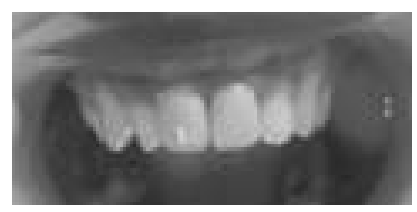

GAMBAR 5.

Mahkota PFM pada gigi 11 dan 21.

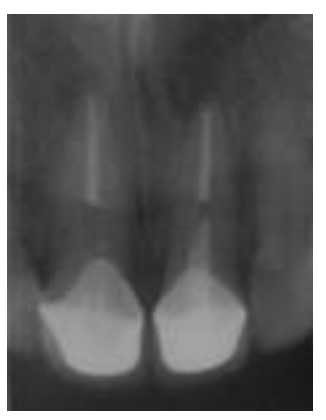

GAMBAR6.

Pemanggilan ulang satu tahun setelah perawatan.

\section{PEMBAHASAN}

Lesi pada periodontitis apikalis merupakan akibat respons inflamasi akibat infeksi bakteri pada saluran akar. Radiolusensi periapikal biasanya seringkali terjadi pada lesi ini. Periodontitis apikalis biasa terdiagnosa secara tidak sengaja melalui pemeriksaan rontgen rutin atau karena adanya nyeri akut hebat pada gigi yang dikeluhkan. Contohnya, pada kasus ini, pasien dapat ditegakkan diagnosisnya setelah dilakukan foto rontgen pada gigi depannya akibat kecelakaan motor.

Bila perawatan saluran akar dilakukan dengan standar yang baik, keberhasilan perawatannya bisa mencapai angka 90\%. Semua lesi periapikal sebaiknya dilakukan perawatan konvensional terlebih dahulu, baru dipertimbangkan dilakukan perawatan bedah. Intervensi bedah hanya dilakukan bila perawatan konvensional gagal, karena efek samping dari pembedahan cukup banyak, di antaranya adalah pembengkakan, nyeri, ketidaknyamanan serta kemungkinan terkenanya daerah anatomis yang berbahaya. ${ }^{5,6}$

Terbentuknya lesi periapeks yang berasal dari gigi nonvital dapat terjadi akibat produksi respons inflamasi pada daerah apeks gigi. Setelah pulpa mengalami nekrosis, sistem saluran akar menjadi tempat berkembangnya kolonisasi mikroorganisme. Akibat dekatnya hubungan fisiopatologis antara pulpa dan periapeks, maka bakteri, jamur dan komponen sel memicu terjadinya proses inflamasi pada jaringan periapeks. Proses inflamasi tersebut secara progresif mampu mempengaruhi fenomena resorpsi. Sehingga, mekanisme inumopatologis tersebut akan mengarah pada terjadinya abses, granuloma atau kista periapeks. Beberapa peneliti melalui berbagai rangkaian penelitian menunujukkan bahwa lesi pulpoperiapeks dapat sembuh tanpa perlu dilakukan intervensi pembedahan. Cvek, Heithersay, Messer dan Stock telah memperlihatkan keberhasilan penatalaksanaan lesi periradikuler yang luas dengan menggunakan kalsium hidroksida sebagai medikasi intrakanal. Pembedahan hanya dilakukan bila gejala dan simptom menetap serta tidak adanya perbaikan secara radiografi. ${ }^{1,2,6}$

Tujuan utama perawatan saluran akar adalah untuk menghilangkan bakteri sebersih mungkin. Penatalaksanaan lesi periapeks yang luas meliputi perawatan saluran akar nonbedah, pembedahan apeks hingga pencabutan. Cairan irigasi dan medikasi intrakanal digunakan untuk membantu mengurangi mikroba yang terdapat pada saluran akar. Pada laporan kasus ini, kalsium hidroksida digunakan sebagai medikasi intrakanal, dan telah memperlihatkan keberhasilannya yang mampu secara efektif menghilangkan bakteri dari saluran akar. Penggunaan kalsium hidroksida selama hampir 6 bulan pada kasus ini memperlihatkan hasil yang baik. Seperti terlihat pada Gambar 3, terlihat diameter lesi radiolusensi menyusut dan mengecil di akar mesial dan bahkan hampir terlihat menghilang pada akar distal. Hal ini sesuai dengan penelitian yang dilakukan oleh Caliskan dan Sen yang menyatakan bahwa penyembuhan periapikal dengan menggunakan kalsium hidroksida memakan waktu berbulan-bulan dan penyembuhannya memperlihatkan hasil yang baik, bahkan pada keadaan defek resorpsi periapikal. Mekanisme kerja kalsium hidroksida masih bersifat spekulatif, namun diperkirakan akibat kemampuan bahannya yang bersifat antiseptik, antieksudatif dan mampu memicu mineralisasi. Hal ini disebabkan kalsium hidroksida mampu memecah atau larut menjadi ion hidroksil dan kalsium pada daerah saluran akar dan periapeks.penggantian medikasi intrakanal kalsium hidroksida secara berkala merupakan hal yang penting dilakukan guna mengurangi intensitas proses inflamasi periapeks, dan juga karena kalsium hidroksida mudah diresorpsi secara progresif oleh cairan periapeks. Medikasi intrakanal kalsium hidroksida mampu mengubah jaringan granulasi inflamasi menjadi jaringan granulasi reparatif dan secara bersamaan dapat mengubah sel mesenkim menjadi sel reparatif ${ }^{7,8,9}$

Kalsium hidroksida digunakan dalam endodontik dalam bentuk pasta yang dapat dengan mudah dimasukkan ke dalam saluran akar. Pasta tersebut merupakan zat alkali yang kuat, yang memiliki pH sekitar 12,5 dalam larutan air, kalsium hidroksida terdisosiasi menjadi kalsium dan ion hidroksil. ${ }^{10}$

Menurut penelitian yang dilakukan Ghose, pemakaian kalsium hidroksida harus dalam keadaan 
berkontak langsung dengan daerah jaringan periapeks agar didapatkan mekanisme osteoinduksi yang diinginkan. Diperkirakan bahwa inflamasi yang diakibatkan difusi kalsium hidroksida pada saluran akar dan jaringan periapeks mampu memecah batas epitelial kistik, hingga mampu membantu penyembuhan lesi yang utuh. ${ }^{11}$

Jika terjadi kegagalan endodontik, perawatan endodontik disarankan perawatan ulang endodontik tanpa bedah periapikal. Secara teoritis lebih baik untuk melakukan perawatan ulang tanpa operasi periradikular. $^{10,11}$

\section{KESIMPULAN}

1. Laporan kasus ini memperlihatkan penyembuhan lesi periapikal yang luas melalui pendekatan nonbedah. Penyembuhan lesi periapeks dicapai melalui penggunaaan kalsium hidroksida. Namun, tetap penting utuk dilakukan observasi dan pengamatan lebih lanjut mengenai prognosis lesi periapeks.

2. Kalsium hidroksida sebagai medikamen intrakanal antar kunjungan dapat membantu untuk menghilangkan kemampuan bakteri bertahan di dalam saluran akar pada lesi periapikal yang luas seperti kista sehingga dicapai keberhasilan perawatan endodontik.

3. Metode konservatif perawatan lesi periapikal yang luas menggunakan kalsium hidroksida dapat menjadi pertimbangan awal sebelum melakukan tindakan bedah.

\section{SARAN}

Pada kasus lesi periapeks yang meluas, perawatan saluran akar dapat dipilih sebagai perawatan yang tepat.

\section{DAFTAR PUSTAKA}

1. Ricucci D, Mannocci F, Ford TR. A study of periapical lesions correlating the presence of a radiopaque lamina with histological findings. Oral Surg Oral Med Oral Pathol Oral Radiol Endod 2006;101:389-94

2. Venugopal P, Kumar SA, Jyothi KN. Successful healing of periapical lesions with non-surgical endodontic approach. J Dent Sci Res 2011; 2:1 6

3. Shailaja S, Suresh BS. Endodontic Microflora -A Review. J Oral Health Comm Dent. 2014;8 (3):160-5

4. Kim D, Kim E, Antimicrobial effect of calcium hydroxide as an intracanal medicament in root canal treatment: a literature review- Part I. In vitro studies. Restor Dent Endod. 2014 Nov; 39(4): 241-52

5. Soares JA, Brito-Júnior M, Silveira FF, Nunes E, Santos SM. Favorable response of an extensive periapical lesion to root canal treatment. J Oral Sci 2008;50:107-11

6. Seltzer S, Soltanoff W, Bender IB. Epithelial proliferation in periapical lesions. Oral Surg Oral Med Oral Pathol 1969;27:111-21.

7. Heithersay GS. Calcium hydroxide in the treatment of pulpless teeth with associated pathology. J Br Endod Soc 1975;8:74-93.

8. Dwivedi S, Dwivedi CD, Chaturvedi TP, Baranwal HC. Management of a large radicular cyst: A non-surgical endodontic approach. Saudi Endod J. 2014;4(3):145-48

9. Farhad A, Mohammadi Z. Calcium hydroxide: A review.
Int Dent J 2005;55:293-301.

10. Saatchi M. Healing of large periapical lesion: A non-surgical endodontic treatment approach. Aust Endod J 2007;33:136-40.

11. Silveira CMM, Sebrao CCN, Sanchez-Ayala A. Apexification of an immature permanent incisor with the use of calcium hydroxide: 16 year follow up of a case. Case Rep Dent 2015 June;13:285-90 